\title{
Problematyka wychowania społecznego w posoborowym nauczaniu Kościoła
}

Wychowanie społeczne może być rozumiane jako przekaz określonych wartości i wzorów zachowań oraz kształtowanie w wychowanku takich postaw, które czynią go aktywnym i pożytecznym członkiem społeczeństwa. W tym znaczeniu uwypukla się wpływ całego dorobku kulturalnego danego społeczeństwa, społecznych zachowań ludzi wprost lub ubocznie spełniających zadania wychowawcze instytucji społecznych'.

Problematyka wychowania społecznego znalazła swoje szczególne miejsce w pedagogice socjologicznej stanowiącej kierunek myśli pedagogicznej Zachodu, który dążył do przezwyciężenia jednostronności zasad swobodnego rozwoju dziecka. W punkcie wyjścia zakładano, że życie jednostkowe rodzi się z całości społecznej, człowiek stanowi jedynie jej cząstką. Pedagogia socjologiczna upatrywała istotę wychowania w procesie uspołecznienia, postrzeganego jako adaptacja jednostki do istniejących warunków społecznych. W tej koncepcji spontanicznemu rozwojowi „od wewnątrz" przeciwstawiono urabianie „od zewnątrz". W praktyce wychowanie zostało sprowadzone do urabiania wychowanka przez grupę społeczną i otaczające środowisko. Ten podstawowy problem wystąpił u czołowych przedstawicieli pedagogiki socjologicznej: Emila Durkheima (1858-1917), Paula Bergemanna (1862-1946), Paula Natorpa (1854-1924), przy czym został przedstawiony w różnych odmianach².

1 Por. J. MAJKA, Wychowanie chrześcijańskie - wychowaniem personalistycznym, w: Wychowanie w rodzinie chrześcijańskiej, red. F. Adamski, Kraków 1982, s. 47.

2 Francuski socjolog i pedagog Emil Durkheim pojmował wychowanie jako jeden ze sposobów działania spoleczeństwa, stanowiącego rzeczywistość realną o charakterze bytu duchowego o własnej świadomości spolecznej, objawiającego się w trzech podstawowych funkcjach: religii, moralności, prawa. Zadaniem wychowania było wywoływanie i rozwinięcie w dziecku określonej liczby stanów fizycznych, umysłowych i moralnych, wymaganych przez społeczeństwo w swej całości i środowisko, w jakim wychowankowi przyjdzie żyć. Inaczej ten problem pojmował niemiecki socjolog i pedagog Paul Bergemann. Według niego wychowanie sprowadza się do przygotowania jednostek do życia w spoleczeństwie, pojmowanym jako organiczna wspólnota ożywiona duchem zbiorowym wielostronnie; rozczłonkowany system duchowy energii narastających ustawicznie i zmieniających się wraz $z$ nowym pokoleniem. $W$ tak ujmowanym 
Wychowanie społeczne jest przedmiotem zainteresowania także ze strony Kościoła. Tej kwestii wiele uwagi poświęcali papieże przed Vaticanum II, przy czym wiele kwestii odnoszących się do wychowania społecznego odnajdujemy w dokumentach Soboru Watykańskiego II oraz w posoborowym nauczaniu Kościoła. W niniejszym przedłożeniu skupię się na treściach, które dotyczą wychowania społecznego realizowanego wobec wszystkich ludzi, a nie tylko ochrzczonych ${ }^{3}$. W tym względzie w nauczaniu Kościoła na plan pierwszy wysu-

wychowaniu treści i cel wychowania czerpane są z bieżącego życia i tym samym ulegają zmianie. Teoria wychowania społecznego według Paula Natorp - niemieckiego filozofa i pedagoga - ma charakter wybitnie idealistyczny. P. Natorp wiąże wychowanie ze stanem moralnej wspólnoty jako ideą życia społecznego. Wspólnotę tę pojmuje jako wewnętrzny związek jednostek istniejący przez jedność świadomości poszczególnych jej członków, której istotę stanowi ludzka wola. Dlatego wychowanie, które urzeczywistnia się w warunkach wspólnoty i służy kształceniu jednostki i życia spolecznego, sprowadza głównie do kształcenia woli. Wynikiem takich oddziaływań wychowawczych jest zupełna jedność moralna jednostek, czyli całkowita wspólnota, urzeczywistniona w prawdziwym socjalizmie.

Wraz z rozwojem pedagogiki socjologicznej powstało kilka odmian wychowania narodowego, państwowego i obywatelskiego. Koncepcje były tworzone tak w Europie, jak i w Stanach Zjednoczonych. Na praktykę oświatową i wychowawczą wywarły wpływ - jakkolwiek destrukcyjny - dwa nurty pedagogiki faszystowskiej: włoski i niemiecki. We Włoszech reformatorem szkolnictwa w duchu faszystowskim był Giovanni Gentile. Pojmował on wychowanie jako proces duchowego stawania się, tworzenia jedności ducha uniwersalnego. $W$ tej koncepcji konkretna osobowość człowieka ulegała unicestwieniu. W Niemczech silny wpływ na pedagogikę faszystowską wywarł socjolog Ferdynand Tönnies, który wprowadził rozróżnienie dwóch form życia społecznego: $z$ dominującą rolą czynnika instytucjonalnego i organizacyjnego oraz skupioną głównie na elementach irracjonalnych i przeżyciowych mającą równocześnie charakter wspólnoty doznawanej bezpośrednio przez uczestników. Pedagogika niemiecka rozwijała głównie tę drugą formę otwierając się równocześnie na ideologie promujące ponadjednostkowy i wspólnotowy charakter życia zbiorowego, obejmujący całą jednostkę niezależnie od jej woli $\mathrm{i}$ decyzji. Ujęcia te zostały wyrażane w koncepcji wspólnoty życia typu narodowosocjalistycznego. Jej głównym teoretykiem był Ernest Krieck. W pierwszej połowie XX w. podjęte zostały próby pewnych powiązań między dwoma przeciwstawionymi kierunkami pedagogiki: naturalistycznym i socjologicznym, podejmowane przez psychologów. Dokonało się to w behawioryzmie Johna Watsona (1878-1950) i w poglądach pedagogicznych Bertranda Russella (1872-1970). Behawioryzm zwrócił uwagę na środowiskowe uwarunkowania postępowania człowieka. Russell sprowadza wychowanie do zadań kształtowania woli i twórczej indywidualności. Jest to koncepcja rozwoju sprawności umysłowej i subtelności uczuciowej człowieka postrzeganego jako indywiduum. Na tej drodze widział możliwość odrodzenia ludzkości. Por. L. GrochowsKI, Oświata i wychowanie w rozwiniętych krajach kapitalistycznych XX wieku, w: Historia wychowania. Wiek XX, t. 2, red. J. Miąso, Warszawa 1981, s. 269-272.

Problematyka wychowania społecznego, zarówno w płaszczyźnie czysto ludzkiej, jak i chrześcijańskiej, jest szerzej zaprezentowana w książce mego autorstwa: „Formacja chrześcijańska dziecka w rodzinie w nauczaniu od Leona XIII do Jana Pawla II", Warszawa 2006. Część zaprezentowanych $w$ tym dziele kwestii - związanych $z$ wychowaniem społecznym - będzie zawarta w niniejszej refleksji. 
wają się dwa główne problemy. Pierwszy dotyczy odkrywania w dziecku powołania do twórczego i odpowiedzialnego uczestnictwa w życiu społecznym. Drugi odnosi się do kształtowania w dziecku postawy odpowiedzialności za budowanie cywilizacji miłości.

\section{Odkrywanie powołania do twórczego i odpowiedzialnego uczestnictwa $w$ życiu społecznym}

Ojcowie Soboru Watykańskiego II stali na stanowisku, że prawdę przyniesioną przez Chrystusa trzeba przepowiedzieć ludziom nowym językiem, dostosować ją do współczesnego świata, uwzględniając znaki czasu. Sobór zaprezentował nowe spojrzenie na Kościół i otaczający go świat. W wymiarze zewnętrznym wyszedł z pozycji defensywy w kierunku otwarcia na świat ${ }^{4}$. Pluralizm, który po drugiej wojnie światowej coraz silniej prezentował się jako usankcjonowana forma bytowania, domagał się od chrześcijaństwa zainteresowania każdą drogą rozwoju obraną przez człowieka. Miało to duże znaczenie dla wykładu dotyczącego wychowania społecznego, w którym uwypuklono konieczność odkrywania w dziecku powołania do twórczego i odpowiedzialnego uczestnictwa w życiu społecznym.

Sobór, odwołując się do danych naturalnych o człowieku i jego naturze, zwrócił uwagę przede wszystkim na prawo, jakie posiada każdy człowiek do wychowania społecznego ${ }^{5}$. Do tej pory w nauczaniu Kościoła mówiono jedynie o czynnym prawie do społecznego wychowania dziecka, jakie posiadają różne instytucje i środowiska odpowiedzialne za wychowanie, zwłaszcza rodzina, Kościół, państwo. Tymczasem w deklaracji o wychowaniu chrześcijańskim „Gravissimum educactionis" wyjaśniono, że godność człowieka daje mu prawo nie tylko do integralnego rozwoju osobowego, ale i do wychowania społecznego ${ }^{6}$. Życie społeczne jest wpisane w naturę człowieka. Jest on bytem społecznym, a więc żyje i działa we wspólnocie, dlatego ma prawo do życia w społeczeństwie, a w konsekwencji do stowarzyszania się, do równości, do partycypacji w życiu społecznym, gospodarczym, kulturalnym i politycznym, do ochrony swych praw ${ }^{7}$. Myśl ta powróciła w konstytucji o Kościele w świecie współczesnym „Gaudium et spes”, przy czym silniej uwypuklono relacje zależności między osobą ludzką i społeczeństwem.

4 Por. M. Maliński, Historia Kościoła, Kraków 1986, s. 253-255.

5 Por. M. Majewski, Idee pedagogiczne św. Jana Bosko w świetle soborowej Deklaracji: O wychowaniu chrześcijańskim, w: $W$ kierunku prawdy, red. B. Bejze, Warszawa 1976, s. 538.

6 Por. Deklaracja o wychowaniu chrześcijańskim, Gravissimum educationis, 28.10.1965, w: Sobór Watykański II: Konstytucje, dekrety, deklaracje, wyd. III, Poznań 1968, 1. Stosowany skrót: DWCH.

7 Por. H. Sковоwsкi, Problematyka praw czlowieka, Warszawa 1996, s. 48. 
"Osoba ludzka - mówiono w konstytucji - jest i powinna być zasadą, podmiotem i celem wszystkich urządzeń społecznych, ponieważ z natury swej koniecznie potrzebuje ona życia społecznego. Ponieważ życie społeczne nie jest dla człowieka tylko czymś dodatkowym, wzrasta on we wszystkich swych przymiotach i staje się zdolny odpowiedzieć swemu powołaniu przez obcowanie $z$ innymi, przez wzajemne usługi i rozmowę z braćmi"s.

Zbieżność tych dwóch dokumentów - deklaracji „Gravissimum educationis” oraz konstytucji „Gaudium et spes” - uwidoczniła się także w treściach dotyczących kierunku formacji społecznej dziecka. W deklaracji o wychowaniu chrześcijańskim uświadamiano, że wychowania społecznego nie może charakteryzować bezcelowość, zupełna dowolność. Jego pierwszym i ostatecznym kryterium jest dobro społeczności, którą człowiek tworzy poprzez sam fakt obecności oraz realizowanie obowiązków wyznaczanych przez społeczność. Informacja ta została przypomniana i potwierdzona w lapidarnym sformułowaniu konstytucji duszpasterskiej o Kościele „Gaudium et spes”, podejmującej równocześnie wątek osoby jako pierwszego i ostatecznego kryterium rozwoju społeczeństwa. Mówiono, że „z natury społecznej człowieka wynika, że istnieje wzajemna zależność między postępem osoby ludzkiej i rozwojem społeczeństwa" ${ }^{\prime 0}$. Stanowisko Ojców Soboru było zbieżne z poglądami eksplikowanymi między innymi w literaturze pedagogiczno-psychologicznej, gdzie zwracano uwagę, że stopniowe doskonalenie się osoby, jej rozwój społeczny, uzdalnia ją do konstruktywnego uczestnictwa w życiu i działalności społeczeństwa ${ }^{11}$. Jakkolwiek cele wychowania determinowane są w znacznej mierze potrzebami społeczeństwa ${ }^{12}$, jednak od jakości rozwoju osobowo-społecznego poszczególnych ludzi tworzących społeczność, zależy w znacznym stopniu jakość społeczeństwa, jego przyszłość, kondycja moralna.

8 Konstytucja duszpasterska o Kościele w świecie współczesnym, Gaudium et spes, 7.12.1965, w: Sobór Watykański II, dz. cyt., 25. Stosowany skrót: KDK.

9 Por. DWCH 1.

10 KDK 25.

1 Por. E. Tкосz, Chrześcijańska formacja mlodzieży w świetle orędzi Jana Pawła II na Światowe Dni Mlodzieży, Katowice 2005, s. 133.

$12 \mathrm{Na}$ określenie celu wychowania wplywają dane pochodzące zarówno z subiektywnych potrzeb wychowanka, jego właściwości psychicznych czy pragnienia doskonalenia własnej osobowości, jak też potrzeby społeczno-kulturalne środowiska. Dlatego też wraz z przeobrażeniami społeczno-politycznymi i kulturalnymi świata zmieniał się naczelny cel wychowania. Każda epoka wytwarzała na tle życia zbiorowego własny ideal wychowawczy. W formułowaniu tych ideałów uczestniczył również Kościół, który stanowiąc Mistyczne Ciało Chrystusa stale jest włączony w społeczność ludzką i od niej uzależniony. Dla przykładu w pierwszych wiekach chrześcijaństwa Kościól postulował przede wszystkim miłość Chrystusa, prowadzącą chrześcijanina do dzielenia się z innymi nawet własnym majątkiem. W wiekach średnich ideałem wychowania był chrześcijanin asceta. W epoce odrodzenia święty dostrzegający w świecie piękno, szukający w'świecie sensu nadprzyrodzonego i odbicia piękna wiecznego. Por. S. DzIEKoŃski, Rozwój wychowawczej myśli Kościoła na przestrzeni wieków, Warszawa 2004, s. 79-80. 
Te dość ogólne sformułowania Sobór uszczegółowił w kolejnych wypowiedziach, co pozwoliło odkryć zasadniczą treść formacji społecznej. Została ona rozwinięta wokół dwóch kluczowych pojęć: jedności czy też solidarności międzyludzkiej i pokoju, zapisanych w ideale wychowania nakreślonym w „Gravissimum educationis" ${ }^{\prime \prime}$. Wpisanie tych wartości w naczelny cel wychowania społecznego było novum w nauce Kościoła, równocześnie zaś stanowiło odpowiedź na potrzeby czasu. Trzeba bowiem zauważyć, że wówczas jednym z palącym problemów był wyścig zbrojeń, ogromne rozmiary przybierała groźba wojny nuklearnej. W tym świetle dostrzega się pełniej, dlaczego w konstytucji „Gaudium et spes" solidarność międzyludzka i pokój zostały wyszczególnione wśród najważniejszych zagadnień współczesnego życia społecznego, wymagających najwięcej uwagi i troski ze strony człowieka ${ }^{14}$. Sobór zamieścił je w grupie praw człowieka jako członka społeczności ogólnoludzkiej ${ }^{15}$. Solidarność międzyludzka i pokój stanowiły też alternatywę dla wzajemnej nieufności i wrogości, konfliktów i udręk wywoływanych i doświadczanych przez samych ludzi ${ }^{16}$.

Determinantą soborowego nauczania stały się dwie encykliki Jana XXIII: „Mater et magistra” oraz „Pacem in terris”. W pierwszym z dokumentów papież postawił osobę ludzką w centrum uwagi, cały system układów społecznych miał być podporządkowany człowiekowi. „Mater et magistra” ograniczała się jednak do fundamentalnych wskazań o godziwym życiu jednostek i społeczeństw, formułowanych nie $\mathrm{w}$ duchu paternalizmu, ale $\mathrm{w}$ oparciu o obiektywne prawdy przechowane w Kościele. „Pacem in teris” natomiast wskazywała na konkretne środki wyprowadzenia świata z impasu i zagwarantowania pokoju. Encyklika była pierwszym autorytatywnym dokumentem Kościoła wprost poświęconym sprawie pokoju, napisanym językiem komunikatywnym, zrozumiałym także dla ludzi spoza kręgu chrześcijańskiego oddziaływania. Papież wyraził się jednoznacznie, że przed światem stoi jedyna alternatywa: samounicestwienie, albo droga do jedności i pokoju. Prawdziwy pokój musi być oparty na prawdzie, sprawiedliwości i wolności, przestrzeganiu praw człowieka. „Pacem in terris” odebrana została jako wielka karta współpracy ludzi bez względu na dzielące ich przekonania, wyznania, systemy polityczne ${ }^{17}$. Jan XXIII odrzucił szereg podstawowych założeń doktrynalno-politycznych wywierających dotąd znaczący wpływ na działalność Kościoła i jego stosunek do świata. „Po pierwsze odrzucono zasadę, w myśl któ-

13 Por. DWCH 1.

14 Por. J. MAJKA, Wprowadzenie do Konstytucji duszpasterskiej o Kościele w świecie wspótczesnym, w: Sobór Watykański II, dz. cyt., s. 535.

15 „Do grupy tych praw należy zaliczyć prawo: do życia w pokoju, do rozwoju, do emigracji, do kooperacji międzynarodowej w dziedzinie gospodarczej, naukowej, kulturalnej, technicznej". H. Skorowski, Problematyka praw czlowieka, dz. cyt., s. 48.

16 Por. KDK 8.

17 Por. Z. Zieliśski, Papiestwo i papieże dwóch ostatnich wieków, cz. II, Poznań 1986, s. 201-202. 
rej wszystko, co pochodzi od człowieka jako istoty materialnej, posiadającej swą naturę, jest grzeszne i prowadzi do złego. Tym samym uznano za błędną zasadę, że jedynie Kościól, jako przedstawiciel porządku nadprzyrodzonego może być źródłem dobra w płaszczyźnie społecznej. Encyklika, wyciągając wnioski z postępów współistnienia w świecie, uznała, że w aktualnym, dalekim przecież od ideału porządku międzynarodowym istnieją elementy i instytucje pozytywne, działające dla dobra człowieka i ludzkości w oparciu o prawo naturalne, wspólne wszystkim ludziom. Kościół, katolicy powinni współdziałać w tych procesach służących dobru człowieka, niezależnie od tego, kto jest inicjatorem, projektodawcą i czołowym wykonawcą zamierzeń" ${ }^{18}$.

Papieskie rozważania o pokoju usytuować można w obszarze antropologii filozoficznej, filozofii kultury, czy filozofii społecznej. Jak we wszelkiej myśli filozoficznej, także w refleksji podjętej w encyklice odnajdujemy: uzasadnienie pokoju jako celu; określenie warunków gwarantujących pokój; charakterystykę czynników utrudniających bądź całkowicie uniemożliwiających wejście na drogę pokoju. Papieskie rozumienie pokoju znacząco różniło się od teorii promujących wyścig zbrojeń, jako jedynej gwarancji utrzymania równowagi na świecie i współżycia między narodami ${ }^{19}$.

Nauka Ojców Soboru o wychowaniu do jedności i pokoju, jakkolwiek czerpała inspiracje z encyklik społecznych Jana XXIII, została ubogacona o wymiar pedagogiczny. Zwrócono uwagę, że pokój i solidarność międzyludzką osiąga się na drodze wychowania. Sobór potwierdził tym samym, że katolicka myśl pedagogiczna, podobnie jak inne systemy wychowania, przywiązuje ogromną wage do budowania pokoju na ziemi, który po drugiej wojnie światowej, zakończonej atomową zagładą Hiroszimy i Nagasaki, stał się jednym z głównych zadań zabiegów wychowawczych ${ }^{20}$. Od 1945 r. rywalizacja kulturalna wszystkich współczesnych systemów wychowania rozwijała się w ramach UNESCO. Głównym

18 J. LeWandowski, Perspektywy pokoju u papieży: bł. Jana XXIII i Jana Pawla II, w: Problematyka pokoju u papieży Jana XXIII i Jana Pawła II, red. J. Lewandowski, Ząbki 2004, s. 39.

19 W „Pacem in terris” pokój został ukazany jako konsekwencja porządku wszechświata, stosunków spolecznych i praw człowieka. Gwarancją pokoju jest wzajemne zaufanie, wola zrozumienia i przebaczenia. Za jeden z czynników najbardziej zagrażających pokojowi uznał papież strach. Jego konsekwencją jest inwestowanie w zbrojenia. Por. Z. Rosińska, Podmiotowe warunki pokoju, w: Problematyka pokoju u papież Jana XXIII i Jana Pawla II, dz. cyt., s. 61-62.

20 Od 1946 r. rozpoczęła się rywalizacja pokojowa na skalę światową trzech systemów wychowania: chrześcijańskiego (prowadzonego przez Kościół katolicki); liberalnego (realizowanego w demokracjach państw kapitalistycznych Europy Zachodniej i Stanów Zjednoczonych Ameryki Północnej); socjalistycznego (obecnego w związku Radzieckim i Krajach demokracji ludowej). Od 1949 r. zaczął się odradzać system wychowania nacjonalistycznego, najpierw w RFN, a po wojnie sueskiej od $1956 \mathrm{r}$. w Egipcie, krajach arabskich oraz w państwach neutralnych, wyzwolonych $z$ ucisku kolonialnego (Indie - 1947, Ghana - 1957, Algeria - 1962). Por. J. Kunowski, Podstawy wspótczesnej pedagogiki, Warszawa 1993, s. 79-80. 
celem tej organizacji stało się utrzymanie pokoju i bezpieczeństwa za pomocą wychowania, nauki i kultury. Statut UNESCO ustawił jakby pięć drogowskazów dla współczesnego wychowania:

- ochrona pokoju musi być zbudowana w umysłach ludzi, ponieważ tutaj wojny mają swój początek;

- naczelny kierunek wychowania powinien być zdeterminowany ideą pacyfizmu i irenizmu;

— wzajemna znajomość dążeń i życia narodów usuwa różnice między nimi i rodzi zaufanie;

- nieodzownym jest wychowanie w duchu sprawiedliwości, wolności i pokoju;

- doktrynę rasizmu, głoszącą nierówność ludzi i ras, zastąpić trzeba zasadą poszanowania godności, równości i szacunku wobec człowieka;

- szerokie rozpowszechnianie kultury i wychowanie ludzkości jest obowiązkiem, który narody muszą wypełnić okazując sobie wzajemną pomoc i troskę;

- fundamentem pokoju jest intelektualna i moralna solidarność ludzka, a nie tylko polityczne i ekonomiczne układy rządów ${ }^{21}$.

${ }^{21}$ W drogowskazach współczesnego wychowania Statut UNESCO uwzględnił główne cele ONZ, do których należą: ochrona przed wojną; poszanowanie praw człowieka, jego godności oraz poszczególnych narodów, niezależnie od ich wielkości; ustalenie warunków sprawiedliwości i poszanowania umów międzynarodowych; popieranie postępu i lepszego poziomu życiowego przy uwzględnieniu większej wolności. U podłoża nowej orientacji wychowania w świecie znalazło się kilka względów. Dostrzeżono, że pierwsza i druga wojna światowa zostały wywołanie nie tylko przyczynami społeczno-politycznymi, ale też postawami moralno-światopoglądowymi. Rozwój kapitalizmu z jego niesprawiedliwością przyczynił się do demoralizacji społeczeństw. Zdechrystianizowana moralność, oparta na sile pieniądza i na przewadze mężczyzny nad kobietą, doprowadziła do podwójnej moralności, zewnętrznie pozornie solidnej, wewnętrznie zgniłej. Warunki te sprzyjały demoralizacji zwłaszcza mlodzieży. W tzw. krajach cywilizowanych XIX w. wzrosła liczba przestępczości nieletnich, pochodzących z lumpenproletariatu. Po pierwszej wojnie światowej zaznaczył się tzw. bunt obyczajowy młodzieży najpierw amerykańskiej, która walcząc $z$ filisterstwem dorosłych dążłła między innymi do usankcjonowania tzw. małżeństw koleżeńskich i małżeństw na próbę. W warstwach wyższych społecznie demoralizacja przejawila się w seksualizmie, w perwersji płciowej, w narkomanii, alkoholizmie, gangach chuligańskich, samobójstwach. Na moralny rozklad całych społeczeństw wpłynęły natomiast wojny, okupacje, nędza, migracje, odejście od tradycyjnej moralności chrześcijańskiej. Do zmiany norm światopoglądowych przyczynił się też ewolucjonizm, który został wykorzystany przez ideologię faszystowsko-nacjonalistyczną do stworzenia teorii rasizmu. Obok przyczyn moralno-światopoglądowych do upadku kultury europejskiej przyczynił się ustrój klasowy. Społeczeństwo podzielone zostało na klasy oświecone, wyższe, panujące oraz klasy społecznych pariasów i nowoczesnego niewolnictwa pracy. Miejsce dawnej arystokracji rodowej zajęla plutokracja. Polityką i życiem kierowała finansjera. Posiadanie stało się miernikiem wartości człowieka. W warunkach dyskryminacji i nieludzkiego traktowania gromadziły się siły rozpaczy i nienawiści. Por. tamże, s. 81-83. 
Postulaty te znalazły swe odzwierciedlenie w nauce Soboru Watykańskiego II, zwlaszcza w pierwszym numerze deklaracji „Gravissimum educationis”. Pokój i prawdziwą jedność - według Vaticanum II - osiąga się na drodze wychowania do dialogu ${ }^{22}$, obejmującego różny zakres: światopoglądowy, społeczny, kulturalny, i prowadzonego z każdym człowiekiem - niezależnie od jego przekonańn ${ }^{23}$. Wychowanie ma umożliwić czlowiekowi nabycie postawy troski o wspólne dobro oraz braterskie współżycie z innymi ${ }^{24}$. Postulat braterstwa ze wszystkimi ludźmi determinuje obowiązek włączenia wychowanka nie tylko „w ojczystą tradycję” i „kulturę własnego narodu”, ale domaga się też kształtowania w wychowanku postawy braterstwa i pokojowego współżycia $z$ innymi narodami na ziemi ${ }^{25}$.

Za tak rozumiany rozwój społeczny dziecka jest odpowiedzialna przede wszystkim rodzina ${ }^{26}$. Ojcowie Soboru uzasadniając swe stanowisko odnieśli się przede wszystkim do socjologicznego wymiaru rodziny. Oddają to wypowiedzi ukazujące rodzinę jako: społeczność rodzącą nowych obywateli ${ }^{27}$; pierwszą i żywotną komórkę społeczeństwa ${ }^{28}$, pierwszą szkołę cnót społecznych, potrzebnych wszelkim społecznościom ${ }^{29}$; społeczność najbardziej odpowiednią do rozwoju człowieka $^{30}$, fundament społeczeństwa ${ }^{31}$. Sobór wyznaczył też rodzinie odpowiednie zadania wychowawcze, dzięki którym dziecko ma kształtować w sobie postawę miłości bliźniego ${ }^{32}$ i odpowiedzialności za dobro wspólne ${ }^{33}$. Cele te zostaną łatwiej osiągnięte, jeśli rodzina świadczyć będzie „(...) czynne miłosierdzie i popierać sprawiedliwość oraz inne dobre uczynki, służące wszystkim braciom znajdującym się w potrzebie" ${ }^{34}$. Ponieważ za kształt rodziny są odpowiedzialni przede wszystkim rodzice, stąd też głównie do nich będzie należało stworzenie w rodzinie atmosfery miłości i szacunku do Boga i ludzi ${ }^{35}$, stopniowe uczenie

22 Por. DWCH 1.

23 Por. P. PORĘBA, Ideal wychowawczy w Deklaracji, „Ateneum Kapłańskie” 60 (1968) 359, s. 411 -412; F. MACHARSKI, Cele apostolskiej działalności katolików świeckich, „Ateneum Kapłańskie” 60 (1968) 358, s. 298.

24 Por. J. TARnowski, Gravissimum educationis, „Ateneum Kapłańskie” 60 (1968) 359, s. 403-404.

25 Por. P. PORĘBA, Ideal wychowawczy w Deklaracji, art. cyt., s. 412.

26 Por. tamże.

27 Por. Konstytucja dogmatyczna o Kościele, Lumen gentium, 21.11.1964, w: Sobór Watykański II, dz. cyt., 11. Stosowany skrót: KK. Por. także DWCH 3.

28 Por. Dekret o apostolstwie świeckich, Apostolicam actuositatem, 18.11.1965, w: Sobór Watykański II, dz. cyt., 11. Stosowany skrót: DA.

29 Por. DWCH 3.

30 Por. KDK 25, 61.

${ }_{31}$ Por. tamże, 52.

32 Por. DWCH 3.

33 Por. DA 11.

34 Tamże.

35 Por. DWCH 3. 
dziecka troski o materialne i duchowe potrzeby bliźniego ${ }^{36}$. Rodzice powinni „tak wychowywać dzieci, by przekraczając krąg rodzinny, obejmowały one duchowo społeczności zarówno kościelne, jak i świeckie”37.

Rodzina i rodzice, jakkolwiek zostali uznani za pierwszych wychowawców odpowiedzialnych za społeczny rozwój dziecka, powinni respektować jego podmiotowość. Jest to kolejny nowy element w nauce Soboru, wypływający bezpośrednio ze zmiany rozumienia wychowania, które zostało sprowadzone do pomocy niesionej wychowankowi w procesie samowychowania ${ }^{38}$. W myśl Vaticanum II za kształtowanie postaw społecznych odpowiedzialny jest też sam wychowanek ${ }^{39}$. Wyraźnie dominujący w przedsoborowym nauczaniu element podporządkowania młodego pokolenia tradycyjnym zasadom życia społecznego przez ludzi starszych, w wypowiedziach Soboru sprowadzony został na dalszy plan $^{40}$. Nie było to równoznaczne $z$ zupełnym wyeliminowaniem zewnętrznego wpływu wychowawczego, który nabiera szczególnej wartości i skuteczności, jeśli pochodzi ze strony rodziny i rodzicó ${ }^{41}$. Ich udział przyjmuje jednak charakter służebny ${ }^{42}$, wspomagający wychowanka, który ukazany został jako pierwszy podmiot tego wychowania i główny jego realizator ${ }^{43}$. Sobór uczulił zatem, aby w społecznym wychowaniu dziecka została zachowana równowaga między wpływem wychowawczym wywieranym przez rodzinę i rodziców a samozaangażowaniem wychowanka.

Podmiotowe traktowanie dziecka było wyrazem otwarcia się Kościoła na wartości współczesnej nauki, zwłaszcza pedagogiki i psychologii ${ }^{44}$. Sobór spełnił w jakiejś mierze postulat aktywizowania dziecka, wysuwany przez zwolenników „nowego wychowania”45. To dążenie do „wchłonięcia” przez Ojców Soboru zdobyczy współczesnej nauki jeszcze bardziej zostało widoczne w szeroko zakreślonym przedmiocie zadań związanych ze społecznym wychowaniem dzieci i młodzieży. Nauczanie Soboru realizowało słuszne postulaty stawiane przez „socjologizm pedagogiczny", domagający się wychowania dla społeczeństwa, określania celów wychowania w oparciu o potrzeby determinowane życiem społecznym.

\footnotetext{
36 Por. DA 30.

37 Tamże.

38 Por. S. Dziekoński, Rozwój wychowawczej myśli Kościoła na przestrzeni wieków, dz. cyt., s. 58.

39 Por. M. MAJEwski, Idee pedagogiczne św. Jana Bosko w świetle soborowej Deklaracji: O wychowaniu chrześcijańskim, art. cyt., s. 537; J. TARNOWSKI, Gravissimum educationis, art. cyt., s. 403-404.

40 Por. M. Majewski, Idee pedagogiczne św. Jana Bosko w świetle soborowej Deklaracji: O wychowaniu chrześcijańskim, art. cyt., s. 537.

41 Por. KK 11; DWCH 3; DA 11, 30; KDK 25, 48, 52, 61.

42 Por. J. TARnowski, Gravissimum educationis, art. cyt., s. 403

${ }_{3}$ Por. M. MAJEWSKI, Idee pedagogiczne św. Jana Bosko w świetle soborowej Deklaracji: O wychowaniu chrześcijańskim, art. cyt., s. 536.

44 Por. J. TARnowski, Gravissimum educationis, art. cyt., s. 403.

45 Por. P. Viotro, Pedagogia generale, Marietti Editori Ldt. 1966, s. 201-202.
} 
Ojcowie Soboru spełnili żądania wysuwane między innymi przez „szkołę pracy”", wskazując na konieczność podjęcia wychowania, które pomogłoby wychowankowi „(...) włączać się czynnie w różne zespoły ludzkiej społeczności (...)"47 .

Przy formułowaniu zadań rodziny w zakresie społecznego wychowānia dziecka Ojcowie Soboru pełniej dostrzegali wartość dorobku kultury ogólnoludzkiej. Wskazanie przez nich na naturalne prawo człowieka do społecznego wychowania odpowiada deklarowanym przez ONZ prawom człowieka do wychowania $w$ ogólności ${ }^{48}$. Podkreślenie natomiast potrzeby wychowania ku braterstwu, zmierzającego do prawdziwej jedności i pokoju na ziemi ${ }^{49}$, bylo uwzględnieniem rodzącej się w świecie po II wojnie światowej idei solidarności międzyludzkiej na wszystkich płaszczyznach życia ${ }^{50}$ oraz dowodem wyjścia Kościoła ku światu, jaki żyje i rozwija się poza bramami świątyni, z równoczesnym zaoferowaniem mu prawdy bez stawiania jakichkolwiek warunków ${ }^{51}$.

\section{Formowanie postawy odpowiedzialności za budowanie „cywilizacji miłości”}

Ducha odnowy soborowej zwierały wypowiedzi Pawła VI. Papież konsekwentnie kontynuował program, jaki przedstawił 22 czerwca 1963 r. w pierwszej odezwie do świata, podejmując zagadnienia dotyczące umocnienia sprawiedliwości w świecie, wolności, prawdy, poszanowania wzajemnych praw i obowiązków ${ }^{52}$. Treści nauczania papieża nie były bez znaczenia dla określenia kierunku społecznej formacji dziecka. Szczególnie silne oddziaływanie miały tutaj wypowiedzi o konieczności włączenia się każdego katolika w ulepszanie porządku doczesnego. W encyklice „Populorum progressio” papież wyjaśniał, że „(..) świeccy, nie czekając biernie na nakazy i wskazania, powinni spontanicznie podjąć inicjatywę przepajania duchem chrześcijańskim mentalności ludzi i ich obyczajów, a także praw i struktur swojego państwa. Zmiany są konieczne, niezbędna jest dogłębna reforma warunków współczesnego życia; przeprowadzając ją należy dołożyć wszelkich starań, ażeby zdecydowanie wszczepiać w to ducha Ewangelii" ${ }^{3}$. Wypowiedź ta nie tylko wskazywała pośrednio kierunek formacji

46 Por. J. TARnOwSki, Gravissimum educationis, art. cyt., s. 400-401.

47 DWCH 1.

48 Por. S. Kunowski, Podstawowe zasady wychowania w Deklaracji, „Ateneum Kapłańskie” 60 (1968) 359, s. 415

49 Por. DWCH 1.

50 Por. Z. Zieliński, Papiestwo i papieże dwóch ostatnich wieków, cz. I, Poznań 1986, s. 28-29.

51 Por. tamże, s. 33.

52 Por. Z. Zieliński, Papiestwo i papieże dwóch ostatnich wieków, cz. II, dz. cyt., s. 217.

53 PAWE VI, Populorum progressio, Rzym 26.03.1967, wydanie polskie w: Encykliki, Jan XXIII, Paweł VI, Jan Paweł II, Warszawa 1981, 81. Stosowany skrót: PP. 
chrześcijańskiej dziecka, ale też dostarczała motywów do jej podjęcia. Podobnie można było odebrać stanowisko papieża wobec krajów dążących do rozwoju.

Paweł VI jako pierwszy z papieży podjął też zagadnienia „nowej cywilizacji”'s4, która może przyjąć niejako podwójne oblicze: zniszczenia i gwałtu albo budowania i miłości. Wobec tendencji zagrażających życiu i rozwojowi jednostek i całych społeczności Paweł VI zachęcał do włączenia się w budowanie „cywilizacji miłości". Sformułowanie to pojawiło się między innymi w przemówieniu na zakończenie Roku Jubileuszowego 25 grudnia 1975 r. Podjął je i rozwinął Jan Paweł II ${ }^{55}$. W encyklice „Dives in misericordia” papież z Polski pisał: „Jeśli Paweł VI wielokrotnie wskazywał na "cywilizację miłości» jako cel, do którego winny zmierzać wszelkie wysiłki w dziedzinie społecznej i kulturalnej, a także ekonomicznej i politycznej, to wypada powiedzieć, że osiągnięcie tego celu nie będzie możliwe, jeżeli w naszych koncepcjach i realizacjach dotyczących tych rozległych i złożonych dziedzin ludzkiego współżycia będziemy się zatrzymywać przy zasadzie "oko za oko i ząb za ząb", a nie postaramy się jej zasadniczo przetworzyć i uzupełnić innym duchem" ${ }^{\text {"6 }}$. Pod pojęciem „inny duch" ukryta została przede wszystkim idea niezwykle bogatej w treści i znaczenie miłości. Jej poświęcił papież szczególną uwagę, o czym zdecydowały głównie dwa względy: przejawy egoizmu zataczające coraz szersze kręgi oraz potęga miłości jako jedynie skutecznej alternatywy dla „cywilizacji śmierci”, dla społeczeństwa wstrząsanego i rozbitego przez napięcia i konflikty generowane różnymi odcieniami indywidualizmu i egoizmu ${ }^{57}$. Niebezpieczeństwa zagrażające współczesnemu człowiekowi papież scharakteryzował między innymi w encyklice "Redemptor hominis”. Mówił wówczas o realnym niebezpieczeństwie poddania człowieczeństwa pod panowanie rzeczy, manipulacji człowiekiem poprzez organizacje życia zbiorowego, system produkcji, środki przekazu społecznego. Sytuację człowieka we współczesnym świecie Jan Paweł II oceniał jako daleką od wymagań milości społecznej, a nawet od obiektywnych wymagań porządku moralnego czy elementarnej sprawiedliwości. Mówił o niewoli, w jaką człowiek został oddany przez cywilizację o profilu materialistycznym i konsumpcyjnym, prowadzącą człowieka do frustracji, rozgoryczenia i rozpaczy. Sytuację, w jakiej znalazł się człowiek, papież nazwał wielkim dramatem i zauważył, że wobec tych zjawisk nikt nie może przejść obo-

54 PAWEE VI, List apostolski Octogesima adveniens, Rzym 14.05.1971, wydanie polskie w: Encykliki, Jan XXIII, Paweł VI, Jan Pawel II, tekst łacińsko-polski, Warszawa 1981, 7. Stosowany skrót: OA.

55 Por. W. Seremak, Cywilizacja milości, w: Leksykon duchowości katolickiej, red. M. Chmielewski, Lublin-Kraków 2002, s. 154.

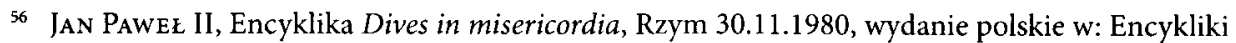
Ojca Świętego Jana Pawła II, t. 1, Kraków 1996, 14. Stosowany skrót: DiM.

57 Por. JAN PAWEe II, Adhortacja apostolska Familiaris consortio, Rzym 22.11.1981, wydanie polskie Wrocław 1994, 37. Stosowany skrót: FC. 
jętnie ${ }^{58}$. Alternatywą na dostrzegane zło i wyrządzaną krzywdę może być jedynie miłość.

W nauczaniu papieża miłość została ukazana jako fundamentalna postawa etyczna w ramach życia społecznego. W wymiarze społecznym miłość jest otwarta na wszystko i wszystkich ${ }^{59}$. Jej praktykowanie można zaś ująć w dwóch perspektywach: negatywnej i pozytywnej. W tej pierwszej miłość społeczna sprzeciwia się i odrzuca wszelkie przejawy przemocy, gwałtu i ucisku, czyli temu wszystkiemu, co wyraża chęć zapanowania nad człowiekiem. W wymiarze pozytywnym miłość społeczna prowadzi do pełnego zaangażowania się na rzecz tworzenia dobra wspólnego, jest siłą prowadzącą do braterstwa między ludźmi i ich wzajemnej współodpowiedzialności. W tym miejscu odsłania się w całej pełni personalistyczny charakter „cywilizacji miłości”. Papieskie wezwanie do społecznej miłości, rozumianej jako służba innym ludziom, jest zgodne porządkiem miłości orędzia ewangelicznego ${ }^{60}$.

W ujęciu Jana Pawła II miłość jest podstawowym środowiskiem właściwego i pełnego rozwoju człowieka. Źródłem tej życiodajnej miłości jest Bóg, a uprzywilejowanym miejscem jej ciągłego objawiania i konkretyzowania sakramentalna rodzina ${ }^{61}$. Dlatego też wychowanie dziecka do budowania cywilizacji miłości Jan Paweł II bezpośrednio powierzył rodzinie. Najsilniej uwidoczniło się to $\mathrm{w}$ adhortacji „Familiaris consortio" wprost traktującej o zadaniach rodziny chrześcijańskiej w świecie współczesnym. Papież odkrywając pierwotny zamysł Boży względem rodziny wyjaśniał, że jest ona głęboką wspólnotą życia i miłości. Istota i zadania rodziny określone są przez milośćć ${ }^{6}$. Dlatego też jest ona „szkołą bogatszego człowieczeństwa", prowadzoną w ramach codziennego życia. Wyjątkowego znaczenia w tym względzie nabierają: miłość okazywana dzieciom, chorym i starszym, służba wobec wszystkich, dzielenie się dobrami, radościami i cierpieniem. W ten sposób tworzy się komunia wychowawcza, której podstawowym czynnikiem jest wzajemna wymiana wychowawcza dokonująca się pomiędzy rodzicami i dziećmi. W przypadku rodziców wyjątkowo ważną kwestią jest ich postawa służby, czyli posługa podporządkowana dobru ludzkiemu i chrześcijańskiemu, umożliwiająca dzieciom osiągnięcie odpowiedzialnej wolności. Dzieci natomiast włączają się w budowanie rodziny prawdziwie ludzkiej i chrześcijańskiej, kiedy okazują rodzicom miłość, szacunek i posłuszeństwo. Podstawowym warunkiem

58 Por. Jan Pawe II, Encyklika Redemptor hominis, Rzym 4.03.1979, wydanie polskie w: Encykliki Ojca Świętego Jana Pawła II, t. 1, Kraków 1996, 16. Stosowany skrót: RHm.

59 Por. S. СнrobaK, Koncepcja wychowania personalistycznego w nauczaniu Karola Wojtyty - Jana Pawła II, Warszawa 1999, s. 73-74.

60 Por. A. Rynio, Integralne wychowanie w myśli Jana Pawta II, Lublin 2004, s. 135.

${ }_{61}$ Por. B. KŁYs, Rodzina jako uprzywilejowane środowisko milości, w: Wychowanie do mitości, red. K. Majdański, Warszawa 1987, s. 62.

62 Por. FC 17. 
zachowania komunii rodzinnej jest duch ofiary, wyrażany w gotowości do zrozumienia, tolerancji, przebaczenia i pojednania. Komunia ta ulega natomiast zniszczeniu pod wpływem kłótni, niezgody, egoizmu, różnego rodzaju konfliktów i napięćć .

Całość wypowiedzi papieża na temat przygotowania dziecka do odpowiedzialnego uczestnictwa w budowaniu cywilizacji miłości zbiera następujące stwierdzenie: „Rodzina jest pierwszą i podstawową szkołą uspołecznienia: w niej, jako we wspólnocie miłości, uczynienie z siebie daru jest prawem, nadającym kierunek i warunkującym wzrost. Dar z siebie, który ożywia wzajemną miłość małżonków, staje się wzorem i zasadą składania daru z siebie, co powinno dokonywać się we wzajemnych stosunkach braci i sióstr oraz różnych, współżyjących w rodzinie pokoleń. Tak komunia jak uczestnictwo codziennie przeżywane w domu, w chwilach radości i w trudnościach, jest najbardziej konkretną i skuteczną pedagogią dla czynnego, odpowiedzialnego i owocnego włączenia się dzieci w życie społeczne o szerszym zasięgu" 64 .

Stanowisko papieża wyrażone w adhortacji „Familiaris consortio” zostało przywołane w „Liście do Rodzin”, gdzie papież przypomniał wyszczególnione już w adhortacji „Familiaris consortio” dwa główne zadania w budowaniu cywilizacji miłości: budzić świadomość, że człowiek w pełni urzeczywistnia się tylko przez bezinteresowny dar z siebie samego oraz tworzyć komunię miłości w rodzinie ${ }^{65}$. „Bez takiego pojęcia człowieka, osoby - mówił papież - oraz «komunii osób» w rodzinie nie może być cywilizacji miłości"66. O tych zadaniach mówił papież wprost, przy czym pośrednio można bylo wnioskować także o innych, podejmując dokładną analizę zagrożeń „cywilizacji miłości”. Najważniejsze z tych zadań koncentrowało się na wychowaniu dziecka do prawdy pozwalającej odkryć właściwy sens podstawowych pojęć, takich jak: miłość, wolność, osoba, małżeństwo, rodzina. Inne zobowiązywało do kształtowania postawy szacunku do drugiego człowieka. Kolejne wskazywało na konieczność podjęcia takiej formacji ze strony rodziców, która dawałaby pierwszeństwo wartościom duchowym przed materialnymi ${ }^{67}$. „List do Rodzin” okazał się więc pewnego rodzaju komentarzem do problematyki podjętej w „Familiaris consortio”. Opinia ta znajduje swe szersze uzasadnienie, jeśli uwzględni się zauważoną już wcześniej prawdę, że w „Liście do Rodzin” zostało doprecyzowane samo pojęcie „cywilizacji miłości” oraz to, że papież dokładnie zaprezentował najważniejsze jej zagrożenia.

63 Por. tamże, 21.

64 Tamże, 37.

65 Por. JAN Pawet II, List do Rodzin, Rzym 2.02.1994, wydanie polskie Watykan 1994, 13. Stosowany skrót: LR.

66 Tamże.

67 Por. tamże. 
W świetle nauczania Jana Pawła II rodzinna formacja dziecka w duchu cywilizacji miłości służy wielu celom bardziej szczegółowym, między innymi wychowaniu do pokoju i solidarności. W encyklice „Sollicitudo rei socialis” papież wyjaśniał, że solidarność jest szczególnym wyrazem więzi międzyludzkiej, skierowanej zarówno ku dobru ogółu społeczeństwa, jak i poszczególnych ludzi. Solidarność - według Jana Pawła II - jest postawą moralną i społeczną stanowiącą odpowiedź na stosunki we współczesnym świecie determinowane współzależnością występująca na różnych płaszczyznach: gospodarczej, kulturowej, politycznej, a nawet religijnej. Solidarność - wyjaśniał papież - nie jest jedynie nieokreślonym współczuciem czy powierzchownym rozrzewnieniem wobec zła dotykającego innych osób, ale wyraża się w mocnej i trwałej chęci odpowiedzialnego zaangażowania się na rzecz dobra wspólnego, stanowiącej przeciwwagę dla żądzy zysku. Solidarność jest drogą do pokoju i prawdziwego rozwoju ${ }^{68}$.

Jan Paweł II przywoływał idee solidarności, dialogu, braterstwa, pokoju także w innych dokumentach o mniejszej randze niż encyklika. Wokół tych wartości skupiały się między innymi orędzia papieskie kierowane do różnych grup i podejmujące problemy współczesności.

\section{Wnioski}

Reasumując, problematyka wychowania społecznego zajmuje ważne miejsce w nauczaniu Kościoła. W wypowiedziach Soboru Watykańskiego II zwrócono uwagę na konieczność formowania $w$ dziecku podstawy twórczego i odpowiedzialnego uczestnictwa w życiu społecznym. Te kierunki wychowania zostały rozwinięte w nauczaniu posoborowym. Ówcześni papieże zwrócili bowiem uwagę, że integralne wychowanie człowieka domaga się formacji do istotnych wartości życia ludzkiego i stopniowego wprowadzania dziecka w odpowiedzialność za kształtowanie we współczesnym świecie cywilizacji miłości.

Znaczną część wypowiedzi Kościoła i papieży trzeba postrzegać jako reakcją na przeobrażenia zachodzące w świecie. Niezależnie jednak od okresu dziejowego zawsze Kościół podkreślał niezastąpioną i pierwszorzędną rolę rodziny w osobowo-społecznym wychowaniu dziecka. Jest to cecha wspólna wszystkich wypowiedzi papieskich.

68 Por. Jan Pawee II, Encyklika Sollicitudo rei socialis, Rzym 30.12.1987, wydanie polskie w: Encykliki Ojca Świętego Jana Pawła II, t. 1, Kraków 1996, 38-39. Stosowany skrót: SRS. 


\title{
The Issue of Social Education in the Teaching of the Church After Vatican II
}

\begin{abstract}
SUMMARY
The issue of social education has an important place in the teaching of the Church. In the pronouncements of the II Vatican Council the need for the formation of the basis of the constructive and responsible participation of children in social life has been noted. Such directions of education have been developed in the teaching after the Council. Even more strongly has it been underlined that the integral education of man demands formation towards the essential values of human life and a gradual introduction of children to responsibility for the formation of the civilization of love in the contemporary world.

A large part of the pronouncements of the Church and of the Popes must be seen as the reaction to the changes taking place in the world. But, independently from the period of history, the Church has always underlined the irreplaceable and primary role of the family in the personal-social education of the child.
\end{abstract}

